\title{
Produksi Konsentrat Pakan Ruminansia dari Kulit Kopi dan Dedak yang Difermentasi Menggunakan Jamur Tiram Putih (Pleurotus ostreatus)
}

\section{Production of Concentrated Ruminant Feed from Coffee Pulp and Rice Bran Fermented by White Oyster Mushroom (Pleurotus ostreatus)}

\author{
Oktaviani $\mathbf{L}^{1}$, Taufik $\mathbf{I}^{1}$, Abduh MY ${ }^{1}$ \\ ${ }^{1}$ Sekolah Ilmu dan Teknologi Hayati, Institut Teknologi Bandung, Jalan Ganesha No. 10, 40132, Bandung.
}

Oktaviani L., Taufik I, Abduh MY. 2018 - Produksi Konsentrat Pakan Ruminansia dari Kulit Kopi dan Dedak yang Difermentasi Menggunakan Jamur Tiram Putih (Pleurotus ostreatus).JurnalMikologi Indonesia 3(1), 10-24.

\begin{abstract}
Abstrak
Penelitian ini bertujuan untuk menentukan pengaruh penambahan dedak sebagai sumber nitrogen bagi pertumbuhan jamur tiram putih pada substrat limbah kopi. Media kulit kopi diberi penambahan dedak dengan variasi persentase $0 \%, 25 \%, 50 \%$, dan $75 \%$ dari total keseluruhan berat kering substrat. Media ditambahkan $\mathrm{Ca}(\mathrm{OH})_{2}$ dan air untuk mencapai $\mathrm{pH}$ sekitar 6-7 dan kadar air 55\%-60\%. Bibit jamur tiram sebanyak $10 \mathrm{~g}$ dikultivasi pada setiap variasi substrat. Kondisi inkubasi diatur pada suhu $23^{\circ} \mathrm{C}-25^{\circ} \mathrm{C}$ dalam keadaan gelap. Panjang koloni jamur tiram diukur setiap 5 hari. Kadar kafein, tanin, protein, lemak, dan abu diukur setiap 20 hari. Hasil penelitian menunjukkan media campuran kulit kopi dan dedak dengan persentase $25 \%$ kulit kopi dan $75 \%$ dedak dapat mengoptimalkan degradasi senyawa beracun pada kulit kopi danmeningkatkan kandungan protein miselium jamur. Kultivasi jamur tiram putih pada kombinasi media tersebut dapat mengurangi kadar kafein sebesar 7,3\% dan tanin sebesar $79 \%$, serta meningkatkan kadar protein sebesar $8 \%$. Pemanfaatan campuran kedua limbah ini dapat mengurangi polutan dan menghasilkan produk konsentrat pakan ruminansia yang sesuai dengan Standar Nasional Indonesia.
\end{abstract}

Kata kunci - degradasi-kafein-rotein-remediasi-tanin

\begin{abstract}
This study was aimed to determine the optimum rice bran addition for coffee husk waste remediation by white oyster mushroom (Pleurotus ostreatus) to produce concentrated feed for ruminant. Coffee husks were mixed with the following rice bran concentrations: 0\%, $25 \%, 50 \%$, and $75 \%$ of dry weight from the total substrate. Media were added with 1-2 gram $\mathrm{Ca}(\mathrm{OH})_{2}$ and $130 \mathrm{~mL}$ of water until $\mathrm{pH}$ 6-7 and 55\%-60\% of water content. The media were placed inside culture flasks and were sterilized before used as a substrate for the oyster mushroom cultivation. The incubation was set at $23^{\circ} \mathrm{C}-25^{\circ} \mathrm{C}$. Colony growth was measured every 5 days. Caffeine, tannin, protein, fat, and ash contents were measured every 20 days. The results showed that $25 \%$ coffee husk mixed with $75 \%$ rice bran
\end{abstract}


facilitated the degradation of toxic compounds and enhanced protein content. Theoyster mushroom cutivation in the combined media reduced the caffeine content up to $7.3 \%$ and 69\%tannin, and increased the protein content up to $8 \%$. Utilization of coffee husk and rice bran as a concentrated feed may reduce pollution and produce a ruminant feed according to the Indonesian National Standard.

Key words - caffeine-degradation-fat-remediation-tannin

\section{Pendahuluan}

Jawa Barat merupakan salah satu daerah penghasil kopi terbesar di Indonesia. Luas perkebunan kopi di Jawa Barat dapat mencapai 33 ribu hektar dan diperkirakan terus meningkat setiap tahunnya (Direktorat Jenderal Perkebunan 2017). Akan tetapi, perkembangan industri kopi tidak sebanding dengan pengolahan dari limbah kopi yang dihasilkan. Limbah dari proses pengolahan kopi seperti kulit kopi mengandung banyak zat beracun yang berdampak pada polusi lingkungan. Adanya limbah dalam jumlah besar tersebut perlu ditangani dengan pemanfaatan limbah kulit kopi untuk menghasilkan produk yang bermanfaat.

Kulit kopi (coffee husk) merupakan limbah dari proses kering fermentasi biji kopi. Total limbah kulit kopi dapat berjumlah 20-45\% dari berat ceri kopi (Muryanto et al. 2014). Limbah kulit kopi masih mengandung senyawa organik yang bermanfaat seperti gula pereduksi dan protein (Roussos et al. 1995). Namun, kulit kopi juga mengandung kafein dan tannin. Jamur tiram putih (P.ostreatus) merupakan salah satu jamur yang mampu mengonversilignoselulosa serta mendegradasi substansi kafein dan tanin dari substratnya (Fan et al. 2014). Fan et al. (2008) melaporkan bahwa jamur tiram putih dapat mengurangi kandungan kafein sebesar $61 \%$ dan tanin sebesar $79 \%$, serta meningkatkan kandungan protein jamur tiram putih sebesar 9,5\% (Fan et al. 2008).

Pada penelitian yang telah dilakukan, dihasilkan tubuh buah jamur tiram yang dapat dikonsumsi dan miselium jamur pada substrat yang dapat dimanfaatkan sebagai konsentrat pakan ruminansia. Namun,dengan kandunganprotein sebesar 8,2\%, kafein sebesar 0,16\%, dan tanin sebesar $1 \%$, miselium jamur yang diproduksi belum memenuhi standar konsentrat pakan. Rata-rata standar konsentrat pakan untuk ruminansiamengandung protein $14 \%$ (SNI 3148.12009 ). Selain itu, kandungan maksimal dari kafein dan tanin yang terdapat pada pakan masing-masing sebesar 0,12\% dan 0,15\% (Demeke 1989, Aquilina et al. 2014). Kandungan kafein dan tanin yang tinggi pada pakan dapat mengurangi dayapencernaan hewan ternak (Tandi 2010).

Pertumbuhan dan kandungan jamur tiram sangat dipengaruhi oleh kondisi dan komposisi substrat. Salah satu faktor yang berpengaruh adalah sumber nitrogen pada substrat. Semakin tinggi sumber nitrogen dari substrat, semakin tinggi juga kandungan protein dari miselium jamur tiram (Nunes et al. 2012). Hal ini berhubungan dengan jalur metabolisme nitrogen sebagai pembentuk asam amino. Di sisi lain, sumber nitrogen turut berpengaruh terhadap aktivitas enzim lignoselulitik pada jamur. Sumber nitrogen yang tinggi akan menghambat aktivitas enzim pendegradasi lignin dan selulosa (Bellettini et al. 2016). Sumber nitrogen pada medium merupakan salah satu parameter yang perlu diperhatikan karena akan memengaruhi kualitas dari produk pakan ataupun tubuh buah yang dihasilkan. Diantara sumber nitrogen yang baik untuk aktivitas fermentasi jamur tiram putih adalah dedak karena memiliki kandungan protein yang tinggi, yaitu mencapai 16,5 \% (Saunders 1985).

Di dalam penelitian ini, berbagai konsentrasi dedak digunakan untuk melihat pegaruhnya terhadap pertumbuhan jamur tiram puth pada substrat limbah kopi. Selain kandungan nitrogennya yang tinggi, dedak merupakan salah satu produk sampingan dari proses produksi beras yang dapat diperoleh dengan mudah di daerah perkebunan kopi Jawa 
Barat seperti Cianjur, Subang, dan Ciwidey. Dengan adanya bahan baku dilokasi yang berdekatan, diharapkan aplikasi dari hasil penelitian ini akan lebih mudah dilakukan.

\section{Metoda Penelitian}

\section{Formulasi Substrat}

Substrat utama yang digunakan dalam penelitian ini adalah kulit kopi dengan variasi berbagai konsentrasi dedak sebagai sumber nitrogen. Komponen pada setiap kombinasi menunjukkan persentase berat kering masing-masing bahan baku. Formulasi substrat yang digunakan ditunjukkan pada Tabel 1.

Tabel 1 Variasi substrat jamur P.ostreatus

\begin{tabular}{ll}
\hline Variasi & Komponen \\
\hline $\mathbf{1}$ & $100 \%$ kulit kopi \\
$\mathbf{2}$ & $75 \%$ kulit kopi $+25 \%$ dedak \\
$\mathbf{3}$ & $50 \%$ kulit kopi $+50 \%$ dedak \\
$\mathbf{4}$ & $25 \%$ kulit kopi $+75 \%$ dedak \\
\hline
\end{tabular}

Setiap kombinasi medium ditambahkan $\mathrm{Ca}(\mathrm{OH})_{2}$ sebanyak 1-2 g untuk mengatur $\mathrm{pH}$ medium sekitar 6-7. Selanjutnya, media ditambahkan air sebanyak $130 \mathrm{~mL}$ hingga memiliki kadar air 55\%-60\% sehingga berat basah substrat untuk setiap perlakukan per botol adalah 330 g. Masing-masing campuran medium yang terdiri dari 100\% kulit kopi (variasi 1), 75\% kulit kopi dan $25 \%$ dedak (variasi 2), $50 \%$ kulit kopi dan $50 \%$ dedak (variasi 3), dan $25 \%$ kulit kopi dan $75 \%$ dedak (variasi 4) kemudian dimasukkan ke dalam botol kultur. Botol kultur berisi medium ditutup dengan plastik tahan panas dan disterilisasi di dalam autoklaf pada suhu $121^{\circ} \mathrm{C}$ dan tekanan 1,5 atm (Horwitz 2000).

\section{Inokulasi Jamur}

Bibit jamur tiram putih yang ditumbuhkan pada medium jagung sebanyak $10 \mathrm{~g} \mathrm{(10 \%}$ dari berat kering medium) dikultivasi pada setiap kombinasi medium. Kemudian, dilakukan inkubasi di dalam ruang gelap bersuhu $23^{\circ} \mathrm{C}$ sampai dengan $25^{\circ} \mathrm{C}$ selama 40 hari (Horwitz 2000). Pertumbuhan panjang koloni jamur diukur dengan menggunakan jangka sorong setiap 5 hari. Setiap 10 hari, dilakukan pengeringan sampel di dalam oven bersuhu $50^{\circ} \mathrm{C}$ untuk dilakukan pengujian protein, kafein,tanin, abu, dan lemak.

\section{Pengukuran Kadar Protein}

Pengukuran kadar protein dilakukan di Laboratorium Teknik Pangan Universitas Pasundan, Bandung. Metode yang digunakan mengacu pada metode semi mikro Kjedahl dengan beberapa modifikasi. Sebanyak 0,5 g sampel dimasukkan ke dalam labu Kjedahl 100 mL, kemudian ditambahkan dengan $2 \mathrm{~g}$ campuran selen dan $25 \mathrm{~mL} \mathrm{H}_{2} \mathrm{SO}_{4}$ pekat. Labu kemudian dipanaskan hingga larutan berwarna bening. Setelah dingin, $10 \mathrm{~mL}$ larutan tersebut ditambahkan dengan $\mathrm{NaS}_{2} \mathrm{O}_{7} 5 \%$ sebanyak $5 \mathrm{~mL}, \mathrm{NaOH} 30 \%$ sebanyak $30 \mathrm{~mL}$, dan akuades sebanyak $50 \mathrm{~mL}$. Campuran ini kemudian didistilasi dengan penampung berisi $\mathrm{HCl}$. Distilat kemudian ditambahkan indikator fenoftalein dan dititrasi dengan menggunakan $\mathrm{NaOH} 0,1 \mathrm{~N}$ (SNI 01-28911992). Kadar protein dihitung dengan persamaan (1)

$$
\text { Kadar protein }(\%)=\frac{\left(V_{1}-V_{2}\right)(m l) \times N\left(\frac{m o l}{l}\right) \times M r N\left(\frac{g}{m o l}\right) \times 6,25}{w(g)} \times 100
$$

Keterangan:

$\mathrm{V}_{1} \quad=$ volume $\mathrm{NaOH}$ untuk titrasi sampel $(\mathrm{mL})$ 
$\mathrm{V}_{2} \quad=$ volume $\mathrm{NaOH}$ untuk titrasi blanko $(\mathrm{mL})$

$\mathrm{N}=$ normalitas $\mathrm{NaOH}(\mathrm{mol} / \mathrm{L})$

$\mathrm{W}=$ berat sampel $(\mathrm{g})$

$\mathrm{Mr} \mathrm{N}=$ berat molekul nitrogen yang bernilai $14 \mathrm{~g} / \mathrm{mol}$.

\section{Pengukuran Kadar Tanin}

Pengukuran kadar tanin menggunakan metode volumetrik standar dari Association of Official Agricultural Chemists (AOAC) dengan beberapa modifikasi. Pada metode volumetrik ini, digunakan indikator indigo carmine yang didapatkan dengan mencampurkan 6 g padatan indigo carmine dengan $500 \mathrm{~mL}$ akuades dalam keadaan panas. Selanjutnya 50 $\mathrm{mL} \mathrm{H}_{2} \mathrm{SO}_{4} 95 \%-98 \%$ dan $450 \mathrm{~mL}$ akuades ditambahkan setelah larutan dingin.

Pada tahap analisis, sebanyak 0,6 g sampel dimasukkan ke dalam labu Erlenmeyer $250 \mathrm{~mL}$ dan ditambahkan air hingga $50 \mathrm{~mL}$, kemudian dilakukan maserasi selama 4 jam. Sampel dalam air tersebut kemudian disaring menggunakan kertas saring. Filtrat yang diperoleh diambil sebanyak $5 \mathrm{~mL}$ dan dimasukkan ke dalam labu Erlenmeyer $250 \mathrm{~mL}$. Larutan tersebut kemudian ditambahkan $5 \mathrm{~mL}$ larutan indigo carmine dan $130 \mathrm{~mL}$ air. Pada tahap ini, larutan campuran akan berwarna biru. Larutan dititrasi dengan menggunakan $\mathrm{KMnO}_{4}$ sampai warna larutan menjadi kuning keemasan (Atanassova \&ChristovaBagdassarian 2009). Kadar tanin dapat diperoleh dengan menggunakan persamaan (2)

$$
\text { Kadar tanin }(\%)=\frac{\left(V_{1}-V_{2)(m l)} \times 0,004157\left(\frac{g}{m l}\right) \times V_{p(m l)}\right.}{w(g) \times V(m l)} \times 100 \ldots
$$

Keterangan:

$\mathrm{V} \quad=$ volume sampel $(\mathrm{mL})$

$\mathrm{V}_{1} \quad=$ volume $\mathrm{KMnO}_{4}$ untuk titrasi sampel $(\mathrm{mL})$

$\mathrm{V}_{2} \quad=$ volume $\mathrm{KMnO}_{4}$ untuk titrasi blanko $(\mathrm{mL})$

$\mathrm{W} \quad=$ berat sampel kering $(\mathrm{g})$

$\mathrm{Vp} \quad=$ volume untuk preparasi sampel $(50 \mathrm{~mL})$.

\section{Pengukuran Kadar Kafein}

Pengukuran kafein dilakukan dengan menggunakan metode gravimetri hasil modifikasi pengujian yang dilakukan oleh Jacobs pada tahun 1962. Sampel berukuran sekitar 0,8 mm ditimbang sebanyak $1 \mathrm{~g}$ lalu dimasukkan ke dalam labu Erlenmeyer berukuran 250 $\mathrm{mL}$. Kemudian, akuades sebanyak $20 \mathrm{~mL}$ (perbandingan antara berat kering sampel dan volume akuades adalah 1:20) dituangkan ke dalam labu Erlenmeyer tersebut. Selanjutnya, sampel dipanaskan dengan menggunakan pendingin tegak selama 2 jam. Sampel kemudian disaring menggunakan kertas saring. Filtrat ditambahkan sebanyak $2 \mathrm{~g} \mathrm{Na}_{2} \mathrm{CO}_{3}$ dan dipanaskan pada suhu $200^{\circ} \mathrm{C}$ hingga mencapai volume akhir sebesar $10 \mathrm{~mL}$.

Kafein yang terkandung dalam filtrat dipisahkan dengan metode ekstraksi menggunakan pelarut diklorometan dalam corong pisah. Perbandingan volume antara filtrat dengan diklorometan adalah 1:3 (v:v), dengan v adalah volume dalam satuan mililiter. Saat ekstraksi, akan terbentuk dua fasa, fasa berat pada bagian bawah merupakan pelarut diklorometan berisi kafein, sedangkan fasa ringan pada bagian atas merupakan air. Fasa bawah diambil dengan memisahkan secara langsung menggunakan valve pada corong pisah. Larutan diklorometan berisi kafein tersebut kemudian ditambahkan $\mathrm{Na}_{2} \mathrm{SO}_{4}$ anhidrat untuk memisahkan air yang terbawa dalam larutan. Kemudian, dilakukan pemanasan hingga diklorometan menguap dan menyisakan serbuk kafein berwarna putih kekuningan. Serbuk kafein ini ditimbang untuk memperoleh nilai berat kafein (Soraya 2008). Kadar kafein dihitung dengan menggunakan persamaan (3) 


$$
\text { Kadar kafein }(\%)=\frac{\text { Berat } k a f e i n(g)}{\text { Berat } \operatorname{sampel}(g)} \times 100
$$

\section{Pengukuran Kadar Lemak dan Abu}

Pengujian kadar lemak dan abu mengacu pada metode SNI 01-2891-1992. Sampel dengan ukuran partikel lebih dari $1 \mathrm{~mm}^{2}$ dipisahkan dari lemaknya dengan metode ekstraksi menggunakan pelarut n-heksana. Sebanyak $300 \mathrm{~mL}$ pelarut $\mathrm{n}$-heksana dimasukkan ke dalam boiling flask pada set unit soxhlet. Sampel sebanyak $1,1 \mathrm{~g}$ dalam kertas saring terikat dimasukkan ke extraction chamber unit soxhlet. Ekstraksi lemak dilakukan selama 4 jam. Setelah ekstraksi lemak, sampel dikeringkan sampai beratnya konstan. Kadar lemak pada tahap ini dapat dihitung dengan menggunakan persamaan (4)

$$
\text { Kadar lemak }(\%)=\frac{\text { berat sampel setelah ekstraksi lemak }(g)}{\text { berat sampel }(g)} \times 100 \ldots \ldots \ldots \ldots \ldots
$$

Sampel kering kemudian dimasukkan ke dalam labu Erlenmeyer ukuran $250 \mathrm{~mL}$ dan ditambahkan dengan $\mathrm{H}_{2} \mathrm{SO}_{4} 1,25 \%$ sebanyak $50 \mathrm{~mL}$. Campuran kemudian dididihkan dengan pendingin tegak (refluks) selama 30 menit. Selanjutnya, $\mathrm{NaOH} 1,25 \%$ sebanyak $50 \mathrm{~mL}$ dituangkan ke dalam campuran dan dididihkan kembali selama 30 menit. Dalam keadaan panas, larutan disaring dengan menggunakan penyaring buchner. Ampas pada kertas saring kemudian dibilas dengan air panas $100 \mathrm{ml}, \mathrm{H}_{2} \mathrm{SO}_{4} 1,25 \%$ sebanyak $50 \mathrm{ml}$, dan aseton sebanyak $50 \mathrm{ml}$ secara berturut-turut. Cake kemudian dikeringkan dengan oven bersuhu $105^{\circ} \mathrm{C}$ hingga beratnya konstan dan ditimbang.

Ampas dipisahkan dari kertas saring dan dimasukkan ke dalam cawan uap yang telah ditimbang berat kosongnya. Selanjutnya, sampel diabukan di dalam tungku pembakaran (furnace) bersuhu $575^{\circ} \mathrm{C}$ selama 2 jam. Perhitungan kadar abu menggunakan persamaan(5)

$$
\operatorname{Kadar} \mathrm{Abu}(\%)=\frac{\text { berat abu }(g)}{\text { berat sampel }(g)} \times 100
$$

\section{Analisis Statistik}

Signifikansi data dianalisis dengan menggunakan two-way ANOVA. Variabel independen yang terdiri dari variasi penambahan dedak dan waktu kultivasi dianalisis pengaruhnya terhadap variabel dependen kadar kafein, kadar tanin, kadar lemak, dan kadar abu. Hasil dianggap siginifikan apabila memiliki nilai $\mathrm{p}<0,05$.

\section{Hasil}

\section{Pola Pertumbuhan Miselium Jamur P. ostreatus pada Berbagai Variasi Substrat}

Pola pertumbuhan jamur tiram putih pada masing-masing substrat diukur setiap 5 hari selama 40 hari. Berdasarkan penelitian yang telah dilakukan, diperoleh pola pertumbuhan jamur tiram dalam setiap variasi substrat yang ditunjukkan pada Gambar 1 .

Kombinasi substrat yang menghasilkan pertumbuhan jamur tercepat adalah substrat yang terdiri dari 50\% kulit kopi dan 50\% dedak. Pada kombinasi ini, miselium jamur telah memenuhi keseluruhan medium substrat pada hari ke-30 kultivasi. Pada waktu yang sama, pertumbuhan miselium jamur tiram hanya memenuhi $40 \%$ media dengan komposisi $100 \%$ kulit kopi, $60 \%$ media dengan komposisi $75 \%$ kulit kopi dan $25 \%$ dedak, serta $96 \%$ media dengan komposisi $25 \%$ kulit kopi dan $75 \%$ dedak. 


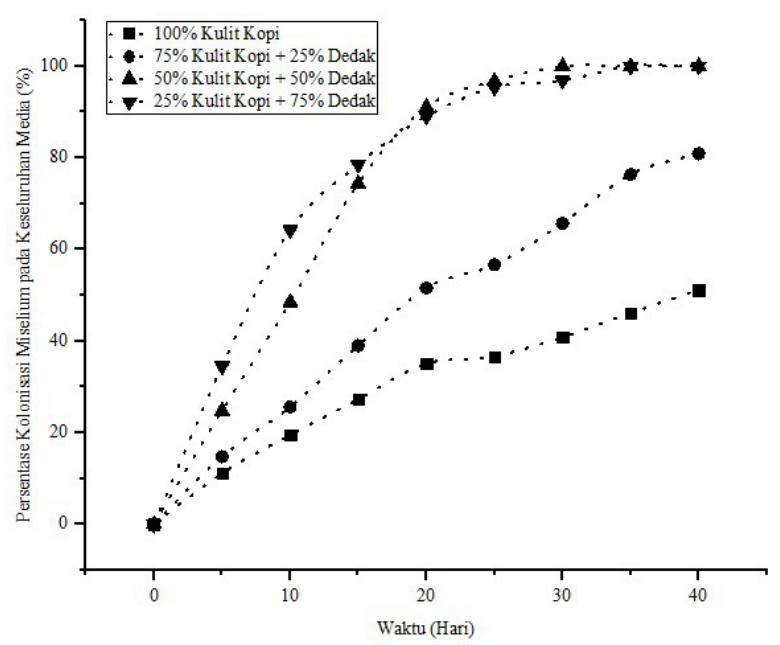

Gambar 1 Pertumbuhan jamur tiram putih pada berbagai komposisi substrat (kultivasiselama 40 hari pada suhu $25^{\circ} \mathrm{C}$ dan $\mathrm{pH} \pm 7$ )

\section{Kadar Protein}

Pengujian kadar protein dilakukan dengan menggunakan basis berat kering sampel. Analisis ini menggunakan sampel media yang terfermentasi jamur tiram putih dengan variasi waktu kultivasi 0, 10, 20, 30, dan 40 hari. Variasi waktu ini digunakan untuk mengetahui pola perubahan kadar protein selama masa pertumbuhan jamur. Hasil pengujian kadar protein pada masing-masing komposisi media ditunjukkan pada Gambar 2. Pada hasil analisis tersebut, diketahui kadar protein meningkat pada setiap variasi substrat. Kombinasi substrat yang menghasilkan kadar akhir protein tertinggi adalah substrat $75 \%$ dedak dan $25 \%$ kulit kopi sedangkan kadar akhir protein terendah dihasilkan dari substrat 100\% kulit kopi. Kadar akhir protein yang tinggi pada substrat dengan variasi $75 \%$ dedak dan $25 \%$ kulit kopi dapat disebabkan oleh kandungan awal media yang memiliki kadar protein yang lebih tinggi dibandingkan dengan variasi yang lainnya, yaitu sebesar $13 \%$.

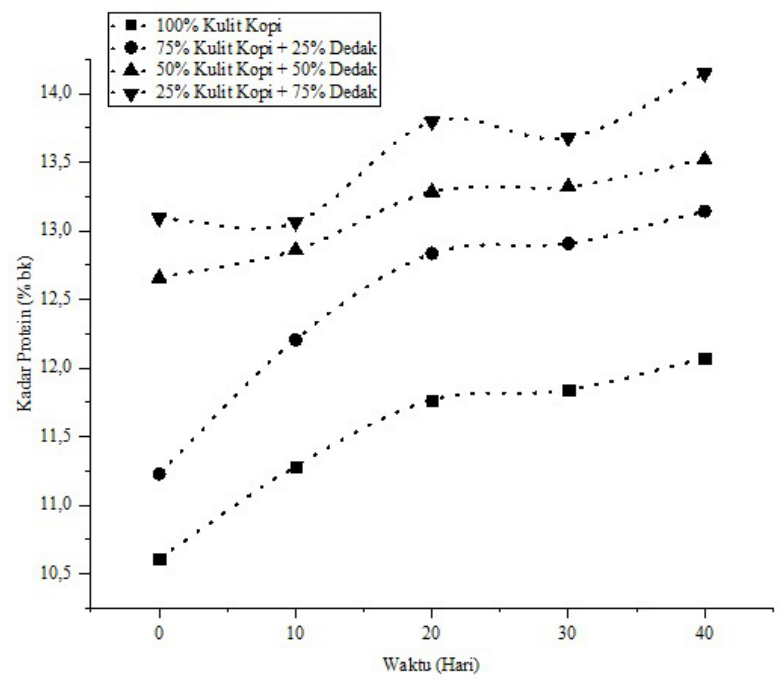

Gambar 2 Kadar protein pada variasi media dan waktu fermentasi (kultivasi selama 40 hari pada suhu $25^{\circ} \mathrm{C}$ dan $\mathrm{pH} \pm 7$ ) 
Berdasarkan nilai persentase peningkatan kadar protein, diperoleh persentase peningkatan pada berbagai variasi substrat masing-masing adalah $13,8 \%$ untuk media $100 \%$ kulit kopi, $17 \%$ untuk media $25 \%$ dedak dan $75 \%$ kulit kopi, 6,8\% untuk media $50 \%$ kulit kopi dan $50 \%$ dedak, serta $8 \%$ untuk media $75 \%$ dedak dan $25 \%$ kulit kopi. Dari segi persentase penambahan kadar protein tersebut, substrat $75 \%$ dedak dan $25 \%$ kulit kopi memiliki nilai penambahan protein yang kecil dibandingkan dengan media 100\% kulit kopi maupun media $25 \%$ dedak dan $75 \%$ kulit kopi. Hal ini dapat dimungkinkan karena perbedaan pembentukan miselium yang akan dibahas lebih detil pada bagian pembahasan.

\section{Kadar Kafein}

Pengukuran kadar kafein dilakukan berdasarkan basis berat kering sampel. Pengujian kadar kafein dilakukan pada sampel kontrol (hari ke-0) dan variasi waktu 20 hari dan 40 hari. Analisis sampel kontrol dan variasi hari ke-40 bertujuan untuk mengetahui perubahan kadar kafein awal dan akhir, sedangkan analisis sampel variasi hari ke-20 dilakukan untuk mengonfirmasi perubahan yang terjadi dari awal hingga akhir waktu kultivasi. Hasil pengujian kadar kafein pada setiap variasi media dan waktu fermentasi ditunjukkan pada Gambar 3. Berdasarkan hasil analisis kadar kafein, dapat diketahui bahwa reduksi kadar kafein tertinggi dihasilkan oleh variasi $100 \%$ kulit kopi dengan nilai persentase reduksi mencapai $49,6 \%$ dan persentase reduksi cenderung terus menurun seiring dengan bertambahnya dedak pada kombinasi substrat.

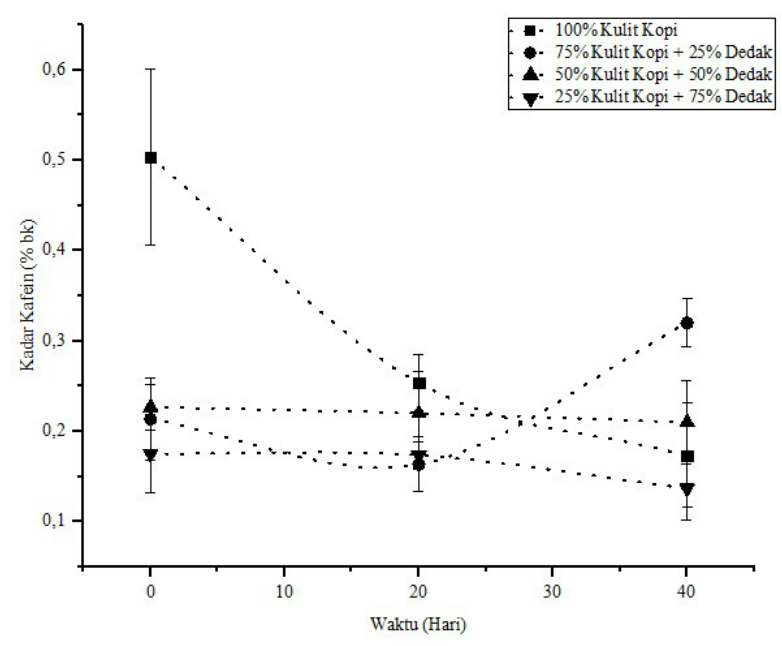

Gambar 3 Kadar kafein pada variasi media dan waktu fermentasi(kultivasi selama 40 hari pada suhu $25^{\circ} \mathrm{C}$ dan $\mathrm{pH} \pm 7$ )

\section{Kadar Tanin}

Pengujian kadar tanin dilakukan dengan basis berupa berat kering sampel. Pengukuran kadar tanin dilakukan pada sampel yang sama dengan pengujian kafein, yaitu sampel kontrol serta sampel variasi waktu hari ke-20 dan hari ke-40. Perubahan kadar tanin pada setiap variasi substrat ditunjukkan pada Gambar 4. Berdasarkan hasil pengujian kadar tanin, dapat diketahui bahwa persentase reduksi tertinggi diperoleh dari media dengan $25 \%$ dedak dan $75 \%$ kulit kopi dengan nilai reduksi $77 \%$ sedangkan persentase reduksi terendah diperoleh dari media dengan $100 \%$ kulit kopi dengan nilai persentase reduksi sebesar $66 \%$. 


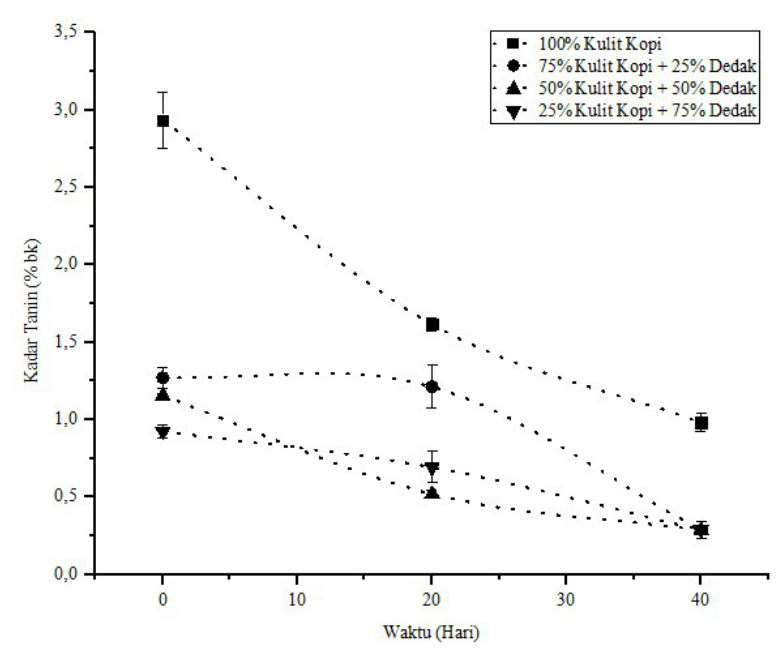

Gambar 4 Kadar tanin pada variasi media dan waktu fermentasi(kultivasi selama 40 hari pada suhu $25^{\circ} \mathrm{C}$ dan $\mathrm{pH} \pm 7$ )

\section{Kadar Lemak dan Abu}

Pengukuran kadarlemak dan abu dilakukan secara paralel dan berbasiskan berat kering sampel. Perubahan kandungan lemak dan abu pada berbagai variasi substrat setelah proses kultivasi masing-masing ditunjukkan pada Gambar 5 dan Gambar 6. Berdasarkan hasil analisis lemak, dapat diketahui bahwa kadar lemak pada semua variasi substrat cenderung menurun setelah adanya kultivasi jamur tiram. Persentase reduksi lemak tertinggi diperoleh dari media dengan 100\% kulit kopi dan persentase terendah diperoleh dari media dengan $75 \%$ dedak dan $25 \%$ kulit kopi.Pada hasil analisis kadar abu, nilai kadar abu cenderung naik pada setiap variasi selama kultivasi jamur tiram. Selain itu, dapat diketahui bahwa kadar abu awal pada setiap media semakin tinggi seiring dengan meningkatnya penambahan dedak.

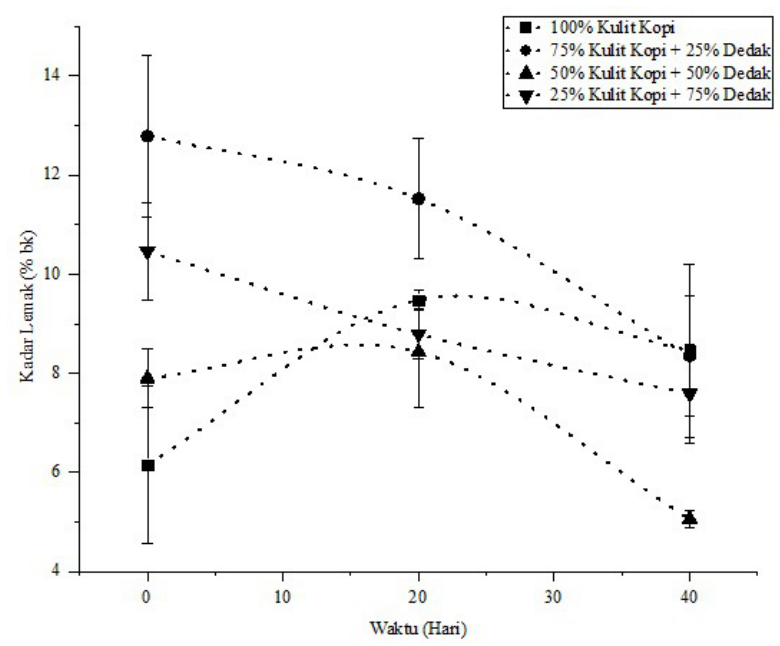

Gambar 5 Kadar lemak pada variasi media dan waktu fermentasi (kultivasi selama 40 hari pada suhu $25^{\circ} \mathrm{C}$ dan $\mathrm{pH} \pm 7$ ) 


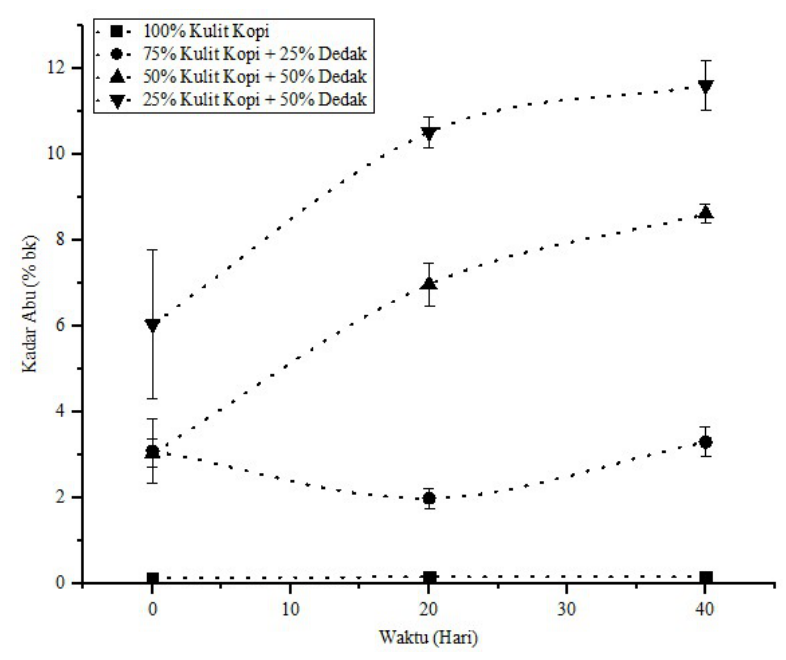

Gambar 6 Kadar abu pada variasi media dan waktu fermentasi (kultivasi selama 40 hari padasuhu $25^{\circ} \mathrm{C}$ dan $\mathrm{pH} \pm 7$ )

\section{Analisis Statistika}

Berdasarkan uji two-way ANOVA, variasi penambahan dedak dan waktu kultivasi jamur tiram putih masing-masing berpengaruh signifikan terhadap kadar kafein, tanin, abu, dan lemak dengan nilai signifikansi (p) kurang dari 0,05.

\section{Pembahasan}

\section{Pola Pertumbuhan Jamur Pleurotus ostreatus pada Berbagai Variasi Substrat}

Berdasarkan pengamatan pertumbuhan jamur tiram pada Gambar 1, dapat diketahuibahwapada substrat dengan media $100 \%$ kulit kopi,jamur tiramhanya mengolonisasi $35 \%$ substrat dalam waktu 20 hari. Berdasarkan penelitian yang dilakukan oleh (Fanet al.2006), jamur tiram dapat mengolonisasi keseluruhan substrat limbah kulit kopi dalam waktu 20 hari. Hal ini dapat disebabkan oleh perbedaan luas permukaan tempat kultivasi. Pada penelitian yang dilakukan oleh Fan et al.(2016), kultivasi dilakukan di dalam plastik tahan panas berdiameter $20 \mathrm{~cm}$, sedangkan pada penelitian ini digunakan botol kultur berdiameter $7 \mathrm{~cm}$. Semakin luas permukaan wadah, akan semakin cepat pertumbuhan jamur tiram. Hal ini berhubungan dengan pertumbuhan vertikal jamur dan aerasi. Padapertumbuhan dengan permukaan yang lebih kecil, aerasi pada bagian bawah akan semakin berkurang sehingga dapat menghambat pertumbuhan miselium jamur tiram (Bellettini et al. 2016).

Berdasarkan pertumbuhan pada setiap variasi media, diketahui bahwa penambahan dedak berpengaruh terhadap pertumbuhan jamur tiram. Media dengan penambahan dedak menunjukkan pertumbuhan yang lebih cepat dibandingkan dengan media 100\% kulit kopi. Perbedaan pola pertumbuhan ini dapat disebabkan protein yang ada di dalam dedak dapat membantu pertumbuhan jamur tiram karena protein merupakan sumber nitrogen organikyang mudah dikonversi dan berperan dalam peningkatan biomassa jamur tiram putih (Bellettini et al. 2016).Sehingga meningkatnya kadar protein pada medium berhubungan langsung dengan meningkatnya pembentukan biomassa miselium jamur tiram yang mengandung kadar protein tinggi (Chahal 1989).

Substrat yang menghasilkan kolonisasi miselium tercepat adalah kombinasi $50 \%$ dedak dan 50\% kulit kopi. Hasil ini tidak berbeda nyata dengan kolonisasi yang terjadi pada media 75\% dedak dan 25\% kulit kopi. Menurut Manu-Tawiah (1988), pada konsentrasi tertentu, penambahan sumber nitrogenorganik dapat meningkatkan pertumbuhan jamur tiram. Namun pada konsentrasi yang lebih tinggi, penambahan sumber nitrogen organik dapat 
sedikit menghambat pertumbuhan jamur tiram. Hal ini berhubungan dengan kondisi $\mathrm{C} / \mathrm{N}$ rasio tertentu yang optimal bagi jamur.

\section{Pengaruh Penambahan Dedak terhadap Kandungan Protein Kulit Kopi Terfermentasi Pleurotus ostreatus}

Berdasarkan hasil pengujian pada Gambar 2, kadar proteinmedia dengan 100\% kulit kopi meningkat sebesar 10,9\% dari kandungan protein awal pada hari ke-20 kultivasi. Hasil ini mendekati dengan penelitian yang dilakukan oleh (Fan et al. 2006). Pada penelitian tersebut disebutkan bahwa protein meningkat sebesar 10,3\% pada hari ke-20 kultivasi kulit kopi.Berdasarkan hasil penelitian, dapat diketahui kandungan protein meningkat seiring dengan lamanya waktu kultivasi jamur tiram. Kadar protein yang meningkat ini dihasilkan dari pertumbuhan jamur tiram yang menghasilkan biomassa miselium tinggi protein (Chahal 1989).

Kadar protein jamur tiram dipengaruhi oleh beberapa faktor, diantaranya komposisi substrat, waktu kultivasi, dan strain jamur yang digunakan (Nunes et al. 2012). Komposisi substrat meliputi kandungan karbon dan nitrogen.Terdapatkorelasi positif antara nitrogen dengankandungan protein miselium jamur. Semakin tinggi kandungan nitrogen substrat maka akan semakin tinggi kandungan protein dari miselium jamur (Picornell-Buendia et al. 2016). Pada penelitian ini, analisis protein miselium jamur tiram tidak dipisahkan dengan substrat sehingga kadar protein pada miselium jamur tidak dapat ditentukan.

Berdasarkan analisis persentase penambahan kadar protein, substrat dengan komposisi $75 \%$ dedak dan $25 \%$ kulit kopi memiliki penambahan kadar protein yang lebih rendah dari media dengan 100\% kulit kopi. Hal ini dapat disebabkan oleh perbedaan kompleksitas medium. Media kulit kopi merupakan media yang lebih kompleks dibandingkan dengan dedak karena sedikit mengandung gula dan nitrogen sederhana. Menurut Laursen (2018), media yang lebih kompleks akan menghasilkan miselium jamur tiram yang lebih tebal dibandingkan dengan media yang sederhana. Oleh karena itu, miselium yang terbentuk pada substrat 100\% kulit kopi dapat dimungkinkan lebih tebal dan mengakumulasi lebih banyak protein walaupun memiliki nilai persetase kolonisasi rendah.

\section{Pengaruh Penambahan Dedak terhadap Kandungan Kafein Substrat Terfermentasi Pleurotus ostreatus}

Berdasarkan hasil pengujian pada Gambar 3, dapat diketahui kafein dalam substrat cenderung turun setelah adanya proses fermentasi oleh jamur tiram putih. Pada penelitian yang telah dilakukanoleh Fan et al.(2006), persentase degradasi kafein setelah 20 hari kultivasi dapat mencapai $62 \%$ pada media dengan 100\% kulit kopi. Pada penelitian ini penurunan kadar kafein setelah 20 hari kultivasi pada media dengan 100\% kulit kopi hanya mencapai 50\%. Perbedaan tersebut dapat disebabkan oleh jamur yang digunakan oleh peneliti. Jamur tiram yang digunakan oleh literatur merupakan jamur tiram dengan strain yang spesifik, yaitu $P$. ostreatus LBP 09. Sedangkan, jamur yang digunakan pada penelitian ini tidak spesifik sampai klasifikasi berdasarkan strain. Perbedaan strain yang digunakan akan mempengaruhi performa dari jamur tiram tersebut.

Secara umum, mekanisme konversi kafein pada fungi ditunjukkan pada Gambar 7. Penurunan kadar kafein terjadi karena adanya enzim-enzim yang terlibat dalam degradasi kafein. Enzim-enzim ini akan mengubah kafein menjadi senyawa theobromine, theophylline, dan paraxanthine. Senyawa ini selanjutnya dikonversi menjadi produk akhir berupa xanthine dan asam amino purin sebagai produk samping (Long \& Dodge 2017).

Pada variasi $100 \%$ kulit kopi, persentase degradasi kafein lebih besar dibandingkan dengan variasi lainnya. Degradasi kafein cenderung menurun seiring dengan bertambahnya persentase penambahan dedak sebagai sumber nitrogen. Nitrogen diperlukan oleh fungi untuk 
pertumbuhan dan produksi metabolit primer. Saat nitrogen dalam bentuk yang lebih sederhana tersedia di dalam substrat, seperti asam amino atau protein, fungi cenderung akan mengonsumsi nitrogen dalam bentuk sederhana tersebut (Gutiérrez-Sánchezet al. 2004). Oleh sebab itu, penambahan dedak berpengaruh terhadap degradasi kafein oleh jamur tiram. Pada penambahan dedak yang lebih banyak, jamur tiram mengonsumsi sumber nitrogen yang terdapat di dalam dedak dan cenderung tidak menggunakan kafein sebagai sumber nitrogen sehingga aktivitas konversi kafein berkurang.Sebaliknya, pada media dengan kadar kafein yang lebih tinggi, jamur tiram cenderung menggunakan kafein untuk dikonversi menjadi sumber nitrogen berupa asam amino sehingga dihasilkan persentase penurunan kadar kafein yang lebih tinggi. Namun, di dalam penelitian ini hal tersebut tidak dapat dibuktikan, karena tidak adanya pengujian terhadap enzim maupun produk sampingan yang dihasilkan selama proses konversisehingga mekanisme degradasi kafein hanya berupa pendekatan dari referensi.

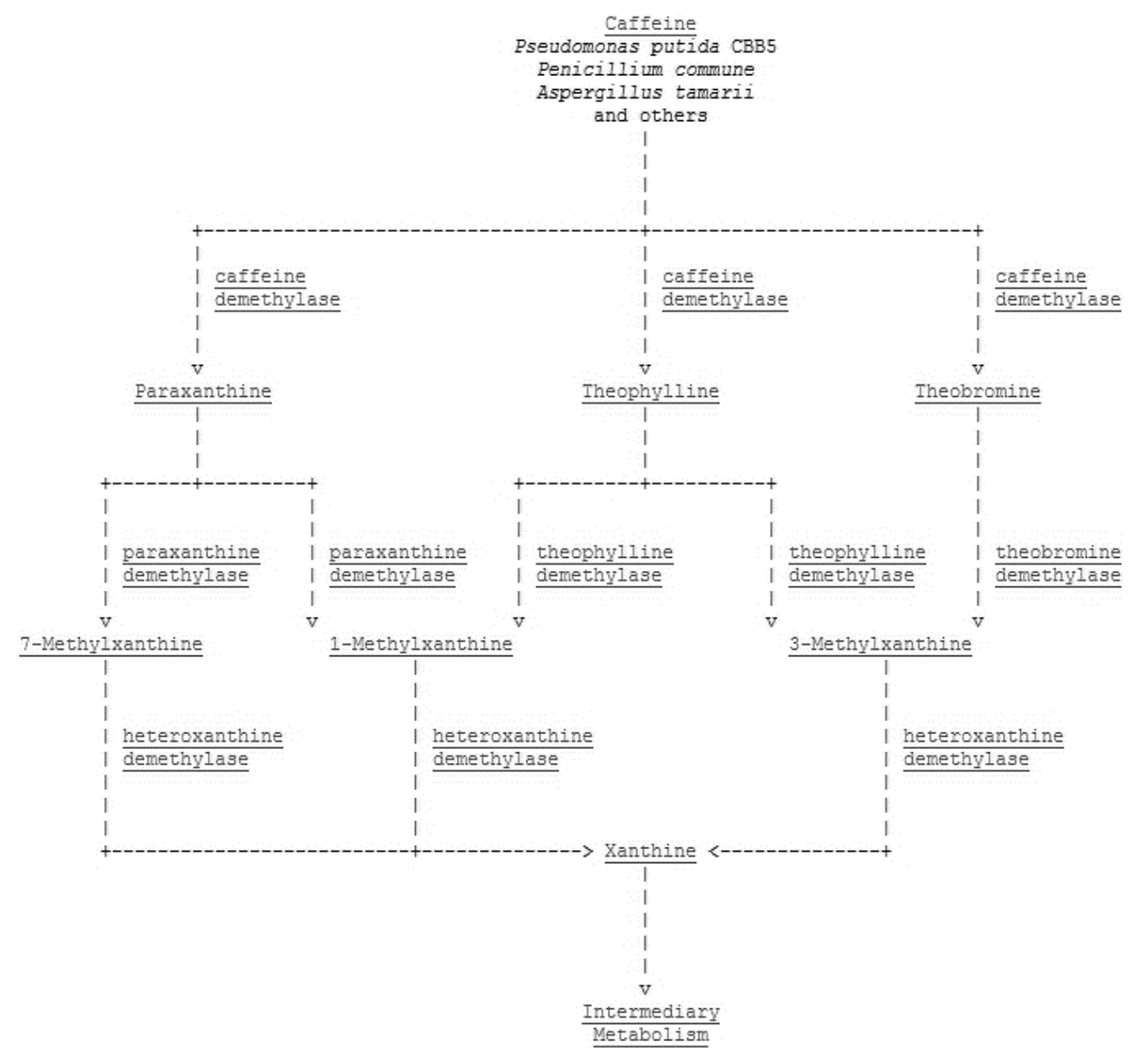

Gambar 7 Jalur metabolism kafein pada fungi (Ling dan Dodge 2017)

\section{Pengaruh Formulasi Substrat terhadap Kandungan Tanin Substrat Terfermentasi Pleurotusk ostreatus}

Berdasarkan hasil pengujian pada Gambar 4, kadar tanin berkurang pada masingmasing variasi media. Pada variasi $100 \%$ kulit kopi, persentase degradasi tanin mencapai 49\% sampai hari ke-20 kultivasi. Hasil ini berbeda dengan referensi acuan. Berdasarkan penelitian yang dilakukanoleh Fan et al.(2006), kadar tanin kulit kopi dapat berkurang hingga 79\% setelah 20 hari kultivasi. Sama seperti hasil pengujian kafein, perbedaan ini dapat disebabkan oleh perbedaan strain jamur yang digunakan. 
Pengurangan kadar tanin setelah adanya fermentasi disebabkan oleh adanya aktivitas enzim tannase yang terdapat di miselium jamur tiram putih (Aftab et al. 2016). Enzim tannase merupakan enzim yang dapat mengonversi tanin menjadi produk utama berupa glukosa dan asam galat. Enzim tannase terdapat di berbagai jenis fungi, seperti Aspergillus sp., Penicillium sp., Ganoderma lucidum, Lentinula lepideus, dan Pleurotus sp.(Sobal et al. 2003).

Berdasarkan hasil penelitian, penambahan dedak sebagai sumber nitrogen mampu meningkatkan degradasi tanin pada kulit kopi. Persentase degradasi tertinggi terjadi pada media 25\% kulit kopi dan75\% dedak, yaitu sebesar 69\%. Perbedaan ini disebabkan oleh produksi enzim tannase yang dipengaruhi oleh ketersediaan nitrogen. Pada dasarnya nitrogen merupakan regulator sintesis enzim sehingga semakin tinggi ketersediaan sumber nitrogen maka semakin tinggi konsentrasi enzim yang dihasilkan. Umumnya, mikroba membutuhkan sumber nitrogen yang relatif sedikit untuk memproduksi enzim karena pada jumlah yang lebih tinggi, nitrogen dapat menekan produksi dari enzim tersebut (Aftab et al. 2016)

\section{Pengaruh Penambahan Dedak terhadap Kandungan Lemak dan Abu Substrat TerfermentasiPleurotus ostreatus}

Berdasarkan hasil pengujian pada Gambar 5, kadar lemak menunjukkan nilai yang cenderung turun, kecuali pada variasi substrat $100 \%$ kulit kopi. Kadar lemak pada kompleks media dan miselium jamur tiram putih semakin menurun seiring dengan lamanya pertumbuhan. Hal ini disebabkan oleh penggunaan lemak sebagai sumber karbon dalam metabolisme untuk menghasilkan energi (Atanassova \&Christova-Bagdassarian 2009). Hasil dari metabolisme ini kemudian digunakan untuk membentuk biomassa miselium jamur yang tinggi protein dan rendah lemak.

Berdasarkan hasil pengujian kadar abu (Gambar 6), media dengan 100\% kulit kopi memiliki kadar abu yang lebih rendah dibandingkan dengan media dengan penambahan dedak, hal ini dapat disebabkan oleh kadar abu yang tinggi pada dedak, yaitu mencapai 925\% (Saunders 1985,Setiawan 2018).Secara keseluruhan, persentase abu pada setiap kombinasi media cenderung meningkat seiring dengan bertambahnya waktu kultivasi. Peningkatan kadar abu ini menandakan adanya peningkatan kadar mineral dan komponen anorganik lain pada jamur tiram (Picornell-Buendía 2016). Selain itu, analisis yang menggunakan sampel berupa kompleks substrat dan miselium dapat menyebabkan kadar abu yang diperoleh lebih tinggi. Semakin lama waktu kultivasi, maka semakin banyak gula sederhana yang digunakan oleh jamur dan menyisakan gula kompleks. Sisa gula kompleks ini yang kemudian akan menjadi bagian dari kadar abu dan meningkatkan nilai kadar abu tersebut.

\section{Analisis Formula Substrat Terbaik untuk Produk Konsentrat Pakan}

Berdasarkan penelitian yang telah dilakukan, dapat dikaji variasi medium yang paling tepat untuk digunakan sebagai konsentrat pakan ruminansia. Waktu kultivasi yang dipilih adalah 40 hari karena menghasilkan perubahan yang signifikan pada setiap perlakuan. Kandungan masing-masing campuran kulit kopi dan dedak yang telah terfermentasi jamur tiram ditunjukkan pada Tabel 2.

Berdasarkan hasil penelitian, variasi media 25\% kulit kopi dan $75 \%$ dedak menghasilkan konsentrat pakan dengan kandungan tanin, kafein, protein, lemak, dan abu yang mendekati Standar Nasional Indonesia. Pada penelitian serupa yang dilakukan oleh Marpaung (2012), kultivasi jamur tiram pada kulit kopi dapat meningkatkan kadar protein pakan hingga mencapai nilai 12,3\%. Pada penelitian ini, penambahan dedakberhasil meningkatkan kadar protein pakan hingga mencapai nilai $14,14 \%$. Peningkatan tersebut dapat 
disebabkan oleh penambahan dedak yang dapat meningkatkan produksi biomassa jamur tiram tinggi protein dan adanya tambahan protein yang secara alami terdapat dalam dedak.

Tabel 2 Kandungan akhir campuran kulit kopi dan dedak yang telah terfermentasi

\begin{tabular}{|c|c|c|c|c|c|}
\hline \multirow[t]{2}{*}{ Parameter } & \multicolumn{5}{|c|}{ Kadar $(\%)$} \\
\hline & $\begin{array}{l}100 \% \\
\text { KK }\end{array}$ & $\begin{array}{l}75 \% \mathrm{KK} \\
+25 \% \mathrm{D}\end{array}$ & $\begin{array}{l}50 \% \mathrm{KK} \\
+50 \% \mathrm{D}\end{array}$ & $\begin{array}{l}25 \% \mathrm{KK} \\
+75 \% \mathrm{D}\end{array}$ & Nilai Standar \\
\hline Tanin & 0,98 & 0,28 & 0,28 & 0,28 & Max. 0,25 (EFSA 2014) \\
\hline Kafein & 0,17 & 0,32 & 0,21 & 0,13 & Max. 0,12 (Demeke 1989) \\
\hline Protein & 12,07 & 13,14 & 13,52 & 14,14 & Min. 14 (SNI 3148.1 2009) \\
\hline Lemak & 8,46 & 8,35 & 5,06 & 7,58 & Max. 7 (SNI 3148.1 2009) \\
\hline $\mathrm{Abu}$ & 0,16 & 3,30 & 8,63 & 11,61 & Max. 12 (SNI 3148.1 2009) \\
\hline
\end{tabular}

Keterangan: $\mathrm{KK}=$ kulit kopi; $\mathrm{D}=$ dedak

Produk konsentrat pakan ternak dari kulit kopi terfermentasi yang dihasilkan dari penelitian ini memiliki beberapa kelebihan. Selain kandungannya yang sesuai dengan standar, konsentrat pakan yang dihasilkan diprediksi mengandung komponen antioksidan. Kulit kopi diketahui mengandung komponen fenolik seperti asam klorogenat $(42,2 \%)$, katekin $(2.2 \%)$, epikatekin $(21,6 \%)$, asam ferulat $(1 \%)$, protocatechuic acid $(1,6 \%)$, dan rutin $(2,1 \%)$ yang memiliki aktivitas antioksidan (Heeger et al. 2017). Antioksidan dibutuhkan untuk menetralisasi keberadaan radikal bebas yang dapat menghancurkan sel (Duangjai et al. 2016). Pada pakan, antioksidan dapat meningkatkan daya tahan tubuh hewan ternak dan mengurangi stress karena perubahan lingkungan (Chauhan et al.2014). Selain itu dari segi pengaplikasian, penelitian ini dapat berperan dalam mengurangi limbah kulit kopi yang selama ini kurang termanfaatkan sehingga dapat mendukung terciptanyazero waste bioindustry berbasis kopi.

\section{Ucapan Terima Kasih}

Penulis mengucapkan terima kasih kepada Kementerian Riset, Teknologi, dan Pendidikan Tinggi Republik Indonesia (RISTEK DIKTI) yang telah mendukung pendanaan penelitian ini(PN-1-22-2018).

\section{Pustaka}

Aftab MN, MukhtarH HaqI. 2016-Production and characterization of tannase from a newly isolated Bacillus subtilis. Pakistan Journal of Botany 48(3), 1263-1271.

AtanassovaM, Christova-BagdassarianV. 2009-Determination of tannins content by titrimetric method for comparison of different plant species. Journal of the University of Chemical Technology and Metallurgy 44(4), 413-415.

Aquilina G, Bampidis V, Bastos M, Costa LG, FlachowskyG, Gralak MA. 2014-Scientific Opinion on the safety and efficacy of tannic acid when used as feed flavouring for all animal species. EFSA Journal 12(10), 3828.

Bellettini MB, Fiorda FA, MaievesHA, Teixeira GL, Ávila S, Hornung PS, Ribani RH. 2016-Factors affecting mushroom Pleurotus spp. Saudi Journal of Biological Sciences. In press http:/ / dx.doi.org/ 10.1016/j.sjbs.2016.12.005

Chahal DS. 1989-Production of protein-rich mycelial biomass of a mushroom, Pleurotus sajor-caju, on corn stover. Journal of fermentation and bioengineering 68(5), 334-338.

Chauhan SS, CeliP, Ponnampalam EN, Leury BJ, LiuF, Dunshea FR. 2014-Antioxidant dynamics in the live animal and implications for ruminant health and product (meat/milk) quality: role of vitamin E and selenium. Animal Production Science 54(10), 1525-1536. 
Demeke S. 1989-The value of coffee pulp alone and in combination with other feeds in sheep nutrition in Ethiopia. In:African Small Ruminant Research and Development: Proceedings of a Conference Held at Bamenda, Cameroon, 18-25 January 1989 (p. 167). ILRI (aka ILCA and ILRAD).

Duangjai A, Suphrom N, Wungrath J, Ontawong A, Nuengchamnong N, Yosboonruang A.2016-Comparison of antioxidant antimicrobial activities and chemical profiles of three coffee (Coffea arabica L.) pulp aqueous extract. Integrative Medicine Research 5(4), 324-331.

Direktorat Jenderal Perkebunan. 2017-Statistika Kopi Indonesia. Sekretariat Jenderal Perkebunan, Kementrian Pertanian.

EFSA Panel on Additives and Products or Substances used in Animal Feed (FEEDAP). 2014-Scientific opinion on the safety and efficacy of tannic acid when used as feed flavouring for all animal species. EFSA Journal 12(10), 3828.

FanL, Soccol AT, Pandey A, Soccol CR. 2003-Cultivation of Pleurotus mushrooms on Brazilian coffee husk and effects of caffeine and tannic acid. Micologia Aplicada International 15(1), 15-21

Fan L, Soccol AT, Pandey A, Vandenberghe LPDS, Soccol CR. 2006-Effect of caffeine and tannins on cultivation and fructification of Pleurotus on coffee husks. Brazilian Journal of Microbiology 37(4), 420-424.

Gutiérrez-Sánchez G, Roussos S, Augur C. 2004-Effect of the nitrogen source on caffeine degradation by Aspergillus tamarii. Letters in applied microbiology38(1), 50-55.

Heeger A, Konsinska-Cagnazzo A, Cantergiani E.2017-Bioactives compound of coffee cherry pulp and its utilisation for production beverage. Food Chemistry 221, 969-975.

Horwitz, William (Ed.). 2000-Official Methods of Analysis of AOAC International. 17th Edition: Agricultural Chemicals, Contaminants, Drugs. Maryland USA: AOAC International.

Laursen A. 2018-The effect of different nitrogen sources on mycelial growth of oyster mushroom, Pleurotus ostreatus. Swedish University of Agricultural Science.

Leinmuller AL, Steingass H, Menke KH. 1991-Tannins in Ruminant Feedstuffs. Anim. Res. Dev. 33, 9-62

Long R, Dodge T. 2017-Caffeine pathway map (fungal). University of Minnesota.

Manu-Tawiah W, Martin AM. 1988-Nitrogen sources and the growth response of Pleurotus ostreatus mushroom mycelium. Canadian Institute of Food Science and Technology Journal 21(2), 194-199.

Marpaung HFR. 2013-Evaluation in vitro of coffee husk fermented with oyster mushrooms (Pleurotus ostreatus) for ruminant feed. Institut Pertanian Bogor.

MuryantoUN., Pramono D, PrasetyoT.2014-Potensi limbah kulit kopi sebagai pakan ayam. JITV19(3), 111-116

NunesMD, da Luz JMR, Paes SA, Ribeiro JJO, da Silva MDCS, Kasuya MCM. 2012Nitrogen supplementation on the productivity and the chemical composition of oyster mushroom. Journal of Food Research 1(2), 113-119

Picornell-Buendía R, Pardo-Giménez A, de Juan-Valero JA 2016-Agronomic assessment of spent substrates for mushroom cultivation. BASE 20 (3),363-374.

Pushpa SM, Manonmani HK. 2008-Bioconversion of coffee industry wastes with white rot fungus Pleurotus florida. Research Journal of Environmental Sciences2(2), 145-150.

Roussos S, Aquiahuatl DA, Trejo-Hernández MR, Perraud M, Favela IG, Ramakrishna E, Viniegra-González G. 1995-Biotechnological management of coffee pulp: isolation, screening, characterization, selection of caffeine-degrading fungi and natural microflora present in coffee pulp and husk. Applied Microbiology and Biotechnology 42(5), 756-762. 
Saunders RM.1985-Rice bran: Composition and potential food uses. Food Reviews International 1(3), 465-495.

Sobal M, Martinez-Carrera D, Rio B, Roussos S. 2003 - Screening of edible mushrooms for polyphenol degradation and tannase production from coffee pulp and coffee husk. In: Roussos S, Soccol CR, Pandey A, Augur C. (eds.), New horizons in biotechnology. Berlin: Springer Science \& Business Media.pp. 89-95.

Setiawan B. 2018-Kandungan Protein Kasar dan Serat Kasar Dedak Padi yang Difermentasi dengan Mikroorganisme Lokal. Doctoral dissertation Universitas Hasanuddin Makassar.

SNI 01-2891-1992. 1992-Cara uji makanan dan minuman, Badan Standar Nasional

SNI 3148.1:2009. 2009-Pakan konsentrat. Badan Standar Nasional.

Soraya N. 2008-Isolasi kafein dari limbah teh hitam CTC jenispowdery secara ekstraksi. Institut Pertanian Bogor. 